\title{
The southern Central Asian mountains as an ancient agricultural mixing zone: new archaeobotanical data from Barikot in the Swat valley of Pakistan
}

\author{
Robert N. Spengler III ${ }^{1}$ [ $\cdot$ Li Tang $^{1} \cdot$ Ayushi Nayak $^{1} \cdot$ Nicole Boivin $^{1,2,3,4} \cdot$ Luca Maria Olivieri $^{5,6}$
}

Received: 24 April 2020 / Accepted: 16 September 2020 / Published online: 7 October 2020

(c) The Author(s) 2020

\begin{abstract}
The mountain foothills of inner Asia have served as a corridor of communication and exchange for at least five millennia, using historically documented trade routes such as the Silk Road and the Tea-Horse Road. Recent research has illustrated the important role that this mountain corridor played in the dispersal of crops and farming technology between northeast and southwest Asia 5,000 to 1,000 years ago. However, the role of the mountain valleys along the southern rim of the Pamirs and Himalaya in facilitating crop dispersals has not yet been fully explored. Notably, ongoing debates over secondary dispersals of Hordeum (barley) and Triticum (wheat) into China and the routes of dispersal for the East Asian crops Oryza sativa (rice), Prunus persica (peach) and P. armeniaca (apricot) into northern India are continuing topics of inquiry. In this article, we add to these discussions by focusing on archaeobotanical remains from the Barikot site (ca. $1200 \mathrm{BCE}-50 \mathrm{CE}$ ) in the Swat valley of northern Pakistan. The Swat valley is an ancient settlement zone in the Hindu Kush-Karakoram foothills, whose cultural features have always had a strong link with inner Asia. The archaeobotanical assemblage illustrates that a diverse array of crops, with origins across Asia, were cultivated around the same settlement. Additionally, these farmers likely implemented seasonal cropping cycles and irrigation that required various labour inputs and water management regimes.
\end{abstract}

Keywords Crop rotation cycles $\cdot$ Archaeobotany $\cdot$ Swat valley $\cdot$ Irrigation $\cdot$ Rice $\cdot$ Northern pakistan

\section{Introduction}

Human populations around the world congregate in biologically rich ecotonal zones; as such, mountain foothills often represent cultural hotspots (Turner et al. 2011).

Communicated by F. Bittmann.

Electronic supplementary material The online version of this article (https://doi.org/10.1007/s00334-020-00798-8) contains supplementary material, which is available to authorized users.

Robert N. Spengler III spengler@shh.mpg.de

1 Department of Archaeology, Max Planck Institute for the Science of Human History, Kahlaischestr. 10, 07745 Jena, Germany

2 School of Social Science, The University of Queensland, Level 2, Michie Building (9), St Lucia, QLD 4072, Australia

3 Department of Anthropology and Archaeology, University of Calgary, 2500 University Dr. NW, Calgary, AB T2N 1NH, Canada
Archaeological research across inner Asia has consistently shown high human population density throughout these ecotones between hills and lowlands, especially in river valleys or alluvial floodplains (Spengler et al. 2013; Frachetti et al. 2018). These river valleys have served as agricultural experimentation zones for millennia (Spengler 2019). Farmers grew both southwest and northeast Asian crops in these foothills for the first time in the late 3rd millennium BCE, representing some of the earliest agriculture in Central Asia (Spengler et al. 2014; Spate et al. 2017; Zhou et al. 2020).

4 Department of Anthropology, National Museum of Natural History, Smithsonian Institution, 10th St. \& Constitution Ave. NW, Washington, DC 20560, USA

5 ISMEO - International Association of Mediterranean and Oriental Studies, Italian Archaeological Mission in Pakistan, Swat, Saidu Sharif 19200, Pakistan

6 Dipartimento Di Studi Sull'Asia E Sull'Africa Mediterranea, Università Ca' Foscari Venezia, Dorsoduro 3462, 30123 Venice, Italy 
The even earlier first agriculture in South Asia has been identified in Balochistan, southwest Pakistan, at the sites of Mehrgarh, Sherikhan Teraki, Sarai Khola and Kili Gui Muhammad, all on alluvial fans (Petrie and Thomas 2012). The ease of irrigation along the alluvial slopes facilitated experimentation with farming practices, such as the development of crop rotation cycles (Miller et al. 2016; Spengler 2019). Over the past few years, archaeobotanical investigations along the inner Asian mountain corridor from the Pamirs north to the Altai (Kuzmina 2008; Frachetti 2012), has greatly expanded our understanding of crop diversification (Liu et al. 2016; Motuzaite Matuzeviciute et al. 2018; Spengler et al. 2018) and technological advances in cultivation (Miller et al. 2016). Yet, further south along the southern rim of the Pamirs, Hindu Kush, Kunlun and Himalaya, there are still questions regarding when and from where certain crops arrived. Historically, farmers there have grown a mixture of crops of East, South and southwest Asian origins together with North African crops, creating a unique economy across northern India and Pakistan. These crops all have differing cultivation requirements, including water needs, growing day lengths and minimal season durations. In this paper, we contribute to the understanding of cultivation systems in the river valleys and alluvial plains of the southern Central Asian mountains, by adding archaeobotanical data from the site of Barikot (ca. 1200 BCE to $50 \mathrm{CE}$ ) in the Swat valley of northern Pakistan (Fig. 1). We further explore three questions: 1 , what water-demanding crops were cultivated in this semi-arid region; 2 , were crop rotation cycles used; and 3 , what role did arboriculture play in the economy.

Sharp transitions between altitudinal ecoclines (ecological gradients determined by the elevation level on a mountain) cause greater biodiversity than the flat steppe or desert regions. The ability to access seasonally available resources at different points on the ecoclines or to shift the elevation of grazing pastures or cultivated fields allows people to adapt better to ecological changes and to use complex foraging or farming strategies. Ethnobotanical studies of wild plant foraging in the Swat valley demonstrate that people use seasonally specific plants from different ecotonal zones and are

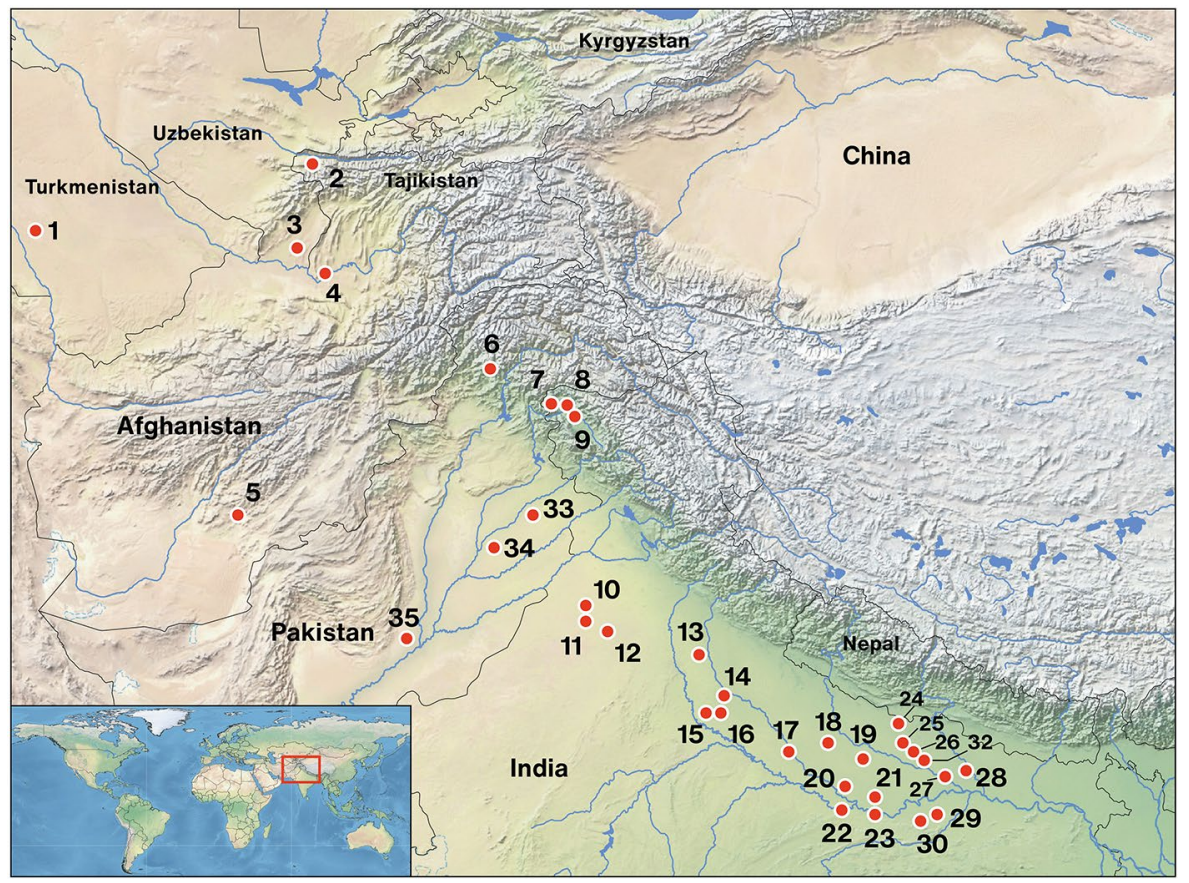

Fig. 1 A map of southern Central Eurasia, with selected agricultural villages or urban sites from the 2nd and 1st millennia BCE with archaeobotanical results. 1, Murghab sites (ca. 3000-1000 вCE); 2, Sarazm (ca. 3500-2000 вСE); 3, Djarkutan (ca. 2500-1500 вСE); 4, Shortughai (ca. 2500-1500 BCE); 5, Mundigak (ca. 4500-2200 BCE); 6, Barikot (ca. 1200 BCE-50 CE); 7, Kanispur (ca. 2700-2000 BCE) and Qasim Bagh (ca. 1800-1400 BCE); 8, Burzahom (ca. 2400-600 вСE); 9, Gufkral (ca. 2400-1600 вСE) and Semthan (ca. 1500-1 вСE); 10, Kunai (ca. 3000-2000 вCE); 11, Bhirrana (ca. 3300-2800 вСE); 12, Siswal (ca. 3800-1500 вСE); 13, Hastinapur (ca. 900-500 вСЕ); 14, Atranjikhera (ca. 2000-200 вCE); 15, Indor-Khera (ca. 1300-600 BCE); 16, Lal Quila (ca. 2000-1500 BCE); 17, Radhan (ca. 2000-1000
BCE); 18, Hulashkhera (ca. 800-200 вСE); 19, Damdama (ca. 38002000 вСе); 20, Sringaverapura (ca. 1000-700 вСе); 21, Hetapatti (ca. 2500-1500 вСE); 22, Kausambi (ca. 600-200 вCE); 23, Jhusi (ca. 2200-1900 ВСE); 24, Lahuradewa (ca. 6000-1500 ВСE); 25, Imlidithkhurd (ca. 2000-800 BCE); 26, Khairadih (ca. 2000-200 BCE); 27, Waina (ca. 1600-600 вСE); 28, Chirand (ca. 2000-1200 вСE); 29, Senuwar (ca. 2200-600 вCE); 30, Raja-Nal-ka-Tila (ca. 1300-700 BCE); 31, Rajdhani (ca. 800-200 BCE); 32, Narhan (ca. 1300-200 вCE); 33. Harappa (ca. 2600-1900 вСЕ); 34, Jalilpu (ca. 2000-1000 вСЕ); 35, Mehrgarh (ca. 7000-2600 BCE); references for the sites and their archaeobotanical assemblages are provided in ESM 2 
aware of resource distribution in time and space (Ahmad et al. 2011; Zeb et al. 2013). Many Central Asian mountain ranges have high glacial peaks, which can represent challenges to cross them, especially during the colder season. As a result, mountain passes have historically been areas of great attention, not only providing routes of passage, but also water and forage for grazing livestock, and they also provide useful archaeological deposits (Frachetti et al. 2018; Taylor et al. 2019). The High Terek pass historically connected Xinjiang to Central Asia through the Alay mountains of Kyrgyzstan, as the Jiptik, Torugart, and Irkeshtam passes did through the Pamir mountains. Further south, the valleys of Kashmir, Khyber and Swat in the western Himalayan Hindu Kush region of Pakistan possess dense archaeological deposits, reflecting the funnelling of human populations through them from the 3rd millennium BCE until today (Bandey 2009; Han 2012; Coningham and Young 2015; Vidale et al. 2015; Olivieri 2017; Olivieri et al. 2019). These valleys have a long history of sedentary agropastoral occupation, relying on a variety of different crops and large deep conical storage pits (Costantini 1987; Lone et al. 1993; Spate et al. 2017). They also witnessed a tumultuous succession of changing empires between ca 500 BCE and $500 \mathrm{CE}$ (Olivieri et al. 2019).

Interestingly, despite strong cultural dispersal through these mountain valleys, there is limited evidence for human gene flow (Jeong et al. 2016). The Swat valley in particular shows an impressive genetic continuity over three millennia from 1200 вCE to $1200 \mathrm{CE}$ (Narasimhan et al. 2019), which can tentatively be read as the consequence of the exceptional stability of farming in Swat. Most of the spread of human genetic material onto the plateau came from the north, where ecoclinal gradients are not as pronounced. In this sense, the mountains of Hindu Kush and southern Himalaya may have served as a genetic barrier to populations at low elevations, who were not physiologically adapted to the thin air and other ecological constraints of the higher land (Jeong et al. 2016). Archaeological research in the Kali Gandahki valley and other neighbouring regions in the southern Himalaya illustrate a system of exchange that connected people in the high mountains to populations lower down, in the upper Indus and Ganges (Ganga) drainage basins (Aldenderfer and Eng 2016; Jeong et al. 2016). Evidence for systematic exchange comes from finds of carnelian and glass beads, serving vessels, cups, bamboo mats and cotton cloth in 1st millennium BCE burials (Eng and Aldenderfer 2017), textiles of cotton, linen and wool, produced in tabbies and twills (Gleba et al. 2016), metal artefacts from the mid 1st millennium CE (Massa et al. 2019) and salt (Dhungel 2002). Additionally, the well-documented Tea-Horse Road ran from the southern China lowlands, in what is now Yunnan, to the high plateau during the late 1st millennium CE (Mair and Hoh 2009). These patterns of exchange between high and low regions seem to exist for the river valleys spanning the entire periphery of the Central Asian montane zone, and this study places the data from Barikot in this cultural context. Therefore, the Barikot site provides an ideal case study for better understanding the movement of material culture, including crops, between South, Central and East Asia.

\section{The Barikot site}

Barikot is located on a silty terrace below a rocky outcrop $\left(34^{\circ} 40^{\prime} \mathrm{N}, 72^{\circ} 12^{\prime} \mathrm{E} ; 799 \mathrm{~m}\right.$ a.s.1.) in the middle of the Swat valley, Khyber Pakhtunkhwa Province, Pakistan, at the confluence of two tributary rivers, the Kandag and Karakar (Vidale and Olivieri 2002). The first evidence of human occupation at Barikot goes back to ca. 1700-1400 BCE (Swat Period IV; Stacul 1987), although occupation in the area dates back to the early 3rd millennium BCE, as evidenced at the nearby cave of Galeghai (Stacul 1987). From 1200 to $800 \mathrm{BCE}$, archaeological data show the presence of a large settlement (roughly 15 ha), including a hilltop acropolis (Callieri et al. 2000), an inner stronghold (Olivieri et al. 2019) and an extensive outer graveyard (Narasimhan et al. 2019). After a phase of abandonment with scarce archaeological data, the construction of an urban centre began at ca. 500 вСE (Olivieri and Iori 2020; Olivieri et al. 2019). The site was already fortified, before the construction of a long urban wall with square towers every $28 \mathrm{~m}$ which was built after $150 \mathrm{BCE}$ at the time of the successors of the Indo-Greek ruler, Menander. At that time the city included an acropolis on the rocky outcrop and covered ca. 12 ha. The city grew in the following centuries, reaching its maximum area at the time of the Kushans around the second century CE. After a series of earthquakes combined with the collapse of the Kushan Empire, the lower city was abandoned towards the end of the third century or slightly later (Olivieri 2011, 2012) and reconstructed along the flanks of the acropolis (Olivieri 2003). The site has been excavated by the Italian archaeological mission in Pakistan, Istituto Italiano per il Medio ed Estremo Oriente (IsMEO), Italian Institute for the Middle and Far East (now ISMEO, International Association of Mediterranean and Oriental Studies), since the 1970s in sondages by G. Stacul (with important contributions by L. Costantini and other specialists) and it has been consistently excavated since 1984, under the directorship of P. Callieri and L.M. Olivieri.

Barikot is located on the highest and most strategic point in the valley. It is characterized by a rocky hill overlooking the Swat river to the north, and a vast terrace sloping down to the south. The area is marked by two tributary valleys, of the rivers Karakar and Kandak, which flow through about $100 \mathrm{~km}^{2}$ of fertile silty plains surrounded by mountains. This area represents the ager (catchment area including agricultural fields) of Barikot (Fig. 2). The city is known in Classical sources as Bazira 
Fig. 2 The site of Barikot, its ager (surrounding land), and the middle Swat valley seen from the southwest (photo by Carla Biagioli, courtesy ACT, Italian Archaeological Mission in Pakistan)

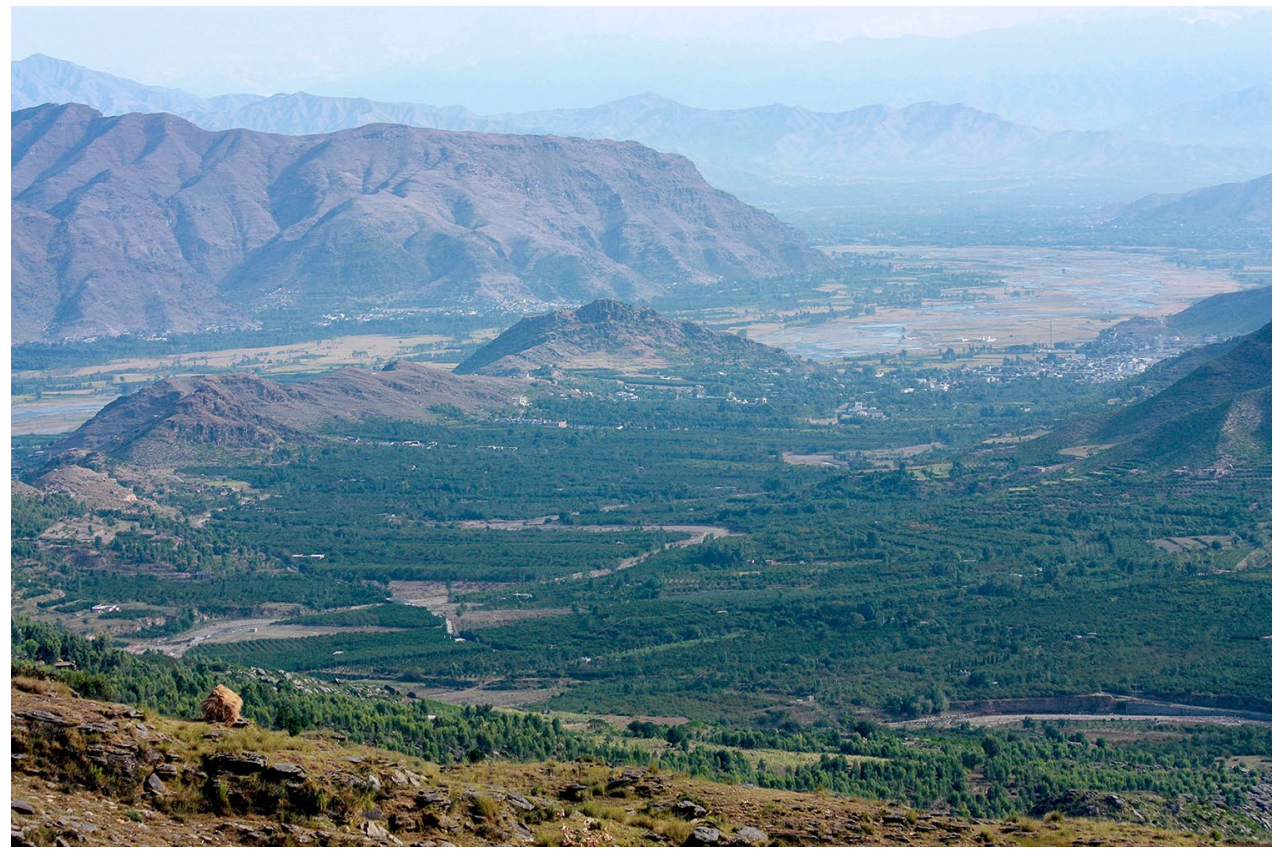

or Beira (Beira $=$ Pakistani and Indo-Iranian va(y)ira and Bazira = Sanskrit vajra, Baums 2019) and in medieval sources as Vajirasthana (von Hinüber 2020). It was an Assakenian stronghold that was besieged and conquered by Alexander the Great in 327 BCE. The area was renowned in antiquity for its fertility; in historical sources the abundance of crops and the size of herds in this area were praised by Arrian of Nicomedia in the early second century CE (Brunt and Robson 1976-83, IV 25, 4). Curtius Rufus) defined it as an urbs opulenta (rich city) in the first century CE (Atkinson and Yardley 2016, VIII 10, 22), the latter being a term clearly indicating agricultural wealth, which is otherwise very rarely used by the Roman historian and only applied to Tarsos, Babylonia, Persepolis and to Bactria (L. Prandi, personal communication). Previous archaeobotanical research in the Swat valley by Costantini (1987) included a section on earlier occupation layers at Barikot (ca. 1700-1400 всE). The present work on Barikot represents the first large scale and systematic archaeobotanical study in this region; the data presented here reveal the agricultural system used across the mountain valleys and alluvial fans in the past; they also helps link ongoing discussions about South and Central Asia. By working on this site we can begin to fill in the gaps in our understanding of the spread of crops across the ancient world.

\section{Methods}

Sediment samples were collected from the site during excavations in 2016 and 2017, from all distinct features and occupation phases in two excavation trenches, $12 \mathrm{~W}$ and $11 \mathrm{~K}$. The first trench was opened outside the Indo-Greek urban wall, the second roughly $100 \mathrm{~m}$ inside the area marked by that wall. The quantity of soil varied between samples, mostly about $7 \mathrm{~L}$ which was the size of the sediment bag used. Since the flotation of sediments was done during the excavation, we decided to keep the time gap between excavation and floating very short by not storing sediment samples, so to minimize the risk of contamination or mixing of samples. The samples were floated in the field using a water overflow machine, as described by Fritz (2005), Pearsall (2000) and Watson (1976). Flotation was organized by L. M. Olivieri and performed by M. Vidale, E. Iori, M. Fantoni, with Mr. Abid, ISMEO field officer at Barikot. The minimum sieve size used for the light fraction was ca. $1.4 \mathrm{~mm}$, and heavy fraction material was not collected. The floated samples were then dried, packaged, and, once licensed by the archaeological authorities in Pakistan, were exported to the archaeobotanical laboratory in Jena, Germany. The export license was granted to L.M. Olivieri as director of the ISMEO mission 
by the Department of Archaeology and Museums, Government of Pakistan. Similarly, the non-objection certificate was issued by the Directorate of Archaeology and Museums, Government of Khyber Pakhtunkhwa.

In the laboratory, the samples were systematically sorted and all botanical remains were identified and quantified (ESM 1). All of the identified botanical remains were carbonized except for a few mineralized Celtis fruitstones, which are prone to mineralization. We identified the botanical remains using a personal comparative collection of plant remains and a number of identification keys, including Cappers and Bekker (2012) and Neef et al. (2012). All domesticated crops are individually reported, with density, ubiquity and abundance counts presented in Table 1. Seeds of wild plants appeared at extremely low densities and all possible weed seeds or dung burning remains are mentioned below. Mean number of individuals (MNI) estimates are not used, but we liberally applied the category of Cerealia to include all domesticated grain fragments that were too broken or damaged to differentiate between wheat and barley. In most cases, if less than $50 \%$ of the complete grain was present, we included it in Cerealia in an attempt not to artificially inflate the abundance counts. The category of Legume was used to describe fragments of domesticated legumes that were too damaged or fragmented to assign to a type. Due to the coarse sieve mesh used, millet grains and most seeds of wild plants were lost during flotation, if they were present in the first place. The loss of any millet grains has significant implications for interpreting seasonal crop cycles and crop diversification. The limitations of these data for interpreting crop complexes and cultivation practices are discussed below.

\section{Results}

The archaeobotanical assemblage from Barikot consists of 159 sediment samples representing 140 individual layers or contexts, which were collected over two separate field seasons. These samples represent a comprehensive blanket sampling of the excavated units, and they should evenly reflect the food plants present over the duration of occupation. In total, the assemblage consists of 5,450 morphologically identified seeds; 934 of those come from the 2016 field season excavations in Trench 12W, 2,642 of them came from the 2016 excavations in Trench $11 \mathrm{~K}$, and 1,874 of them came from the 2017 excavations in Trench $11 \mathrm{~K}$ (ESM 1). In addition to the total sum of identified seeds, there were 596 fragments of Cerealia, and 226 Legume fragments. We do not include Cerealia or Legumes in the total counts, so as not to artificially inflate the crop counts. Surprisingly, there were only 510 fragments of wood larger than $2.0 \mathrm{~mm}$, but these were not identified to species, as there was not a suitable comparative collection of the trees in this region. Of the total 5,450 seeds, 5,301 of those were domesticated grains or legumes. There were also 49 Gossypium arboreum/herbaceum (cotton) seeds. Additionally, there were several fruits and nuts, including 25 Vitis vinifera (grape) pips, 14 Celtis caucasica (hackberry) pips (mostly mineralized), seven Ziziphus nиттиlaria fruitstones, six possible Prunus fruitstone fragments, two each of Juglans regia (walnut) nutshell fragments, Prunus cf. armeniaca (possible apricot) and cf. Daphne, one Rosa sp., and a possible Cucurbita sp. (Fig. 3). The remaining seeds of wild plants include nine Cannabis seeds (a wild morphotype), nine Pooid grass seeds, two each of Cyperaceae, Poaceae, Fabaceae, and one each of Galium sp. and Euphorbia.

Table 1 The main crops at Barikot, ubiquities, densities and abundance measurements by phase

\begin{tabular}{|c|c|c|c|c|c|c|c|c|c|c|}
\hline \multirow[t]{2}{*}{ Phase measurements } & \multicolumn{3}{|l|}{1} & \multicolumn{3}{|l|}{2} & \multicolumn{3}{|l|}{3} & \multirow[t]{2}{*}{ Total counts } \\
\hline & Ubiquity (\%) & Density (seeds/L) & Counts & Ubiquity & Density & Counts & Ubiquity & Density & Counts & \\
\hline Triticum sp. & 48.94 & 0.034 & 83 & 64.56 & 0.033 & 301 & 54.55 & 0.006 & 26 & 410 \\
\hline Hordeum sp. & 85.11 & 0.340 & 833 & 88.61 & 0.127 & 1,154 & 87.88 & 0.055 & 248 & 2,235 \\
\hline Oryza sp. & 89.36 & 0.239 & 586 & 89.87 & 0.078 & 705 & 63.64 & 0.026 & 115 & 1,406 \\
\hline Lens culinaris & 42.55 & 0.052 & 128 & 68.35 & 0.055 & 499 & 51.52 & 0.011 & 51 & 678 \\
\hline Lathyrus sativa & 2.13 & 0 & 1 & 1.27 & 0 & 1 & 0 & 0 & 0 & 2 \\
\hline Pisum sativum & 25.53 & 0.016 & 39 & 60.76 & 0.022 & 196 & 42.42 & 0.012 & 52 & 287 \\
\hline Vigna sp. & 23.40 & 0.012 & 29 & 50.63 & 0.012 & 110 & 15.15 & 0.002 & 11 & 150 \\
\hline Macrotyloma uniflorum & 8.51 & 0.06 & 15 & 26.58 & 0.05 & 47 & 6.06 & 0 & 2 & 64 \\
\hline Gossypium sp. & 2.13 & 0.001 & 2 & 13.92 & 0.002 & 15 & 42.42 & 0.007 & 32 & 49 \\
\hline Vitis vinifera & 6.38 & 0.001 & 3 & 16.46 & 0.002 & 22 & 0 & 0 & 0 & 25 \\
\hline Cerealia & 51.06 & 0.095 & 232 & 62.03 & 0.032 & 294 & 39.39 & 0.016 & 70 & 596 \\
\hline Legumes & 31.91 & 0.019 & 47 & 43.04 & 0.015 & 140 & 42.42 & 0.009 & 39 & 226 \\
\hline
\end{tabular}




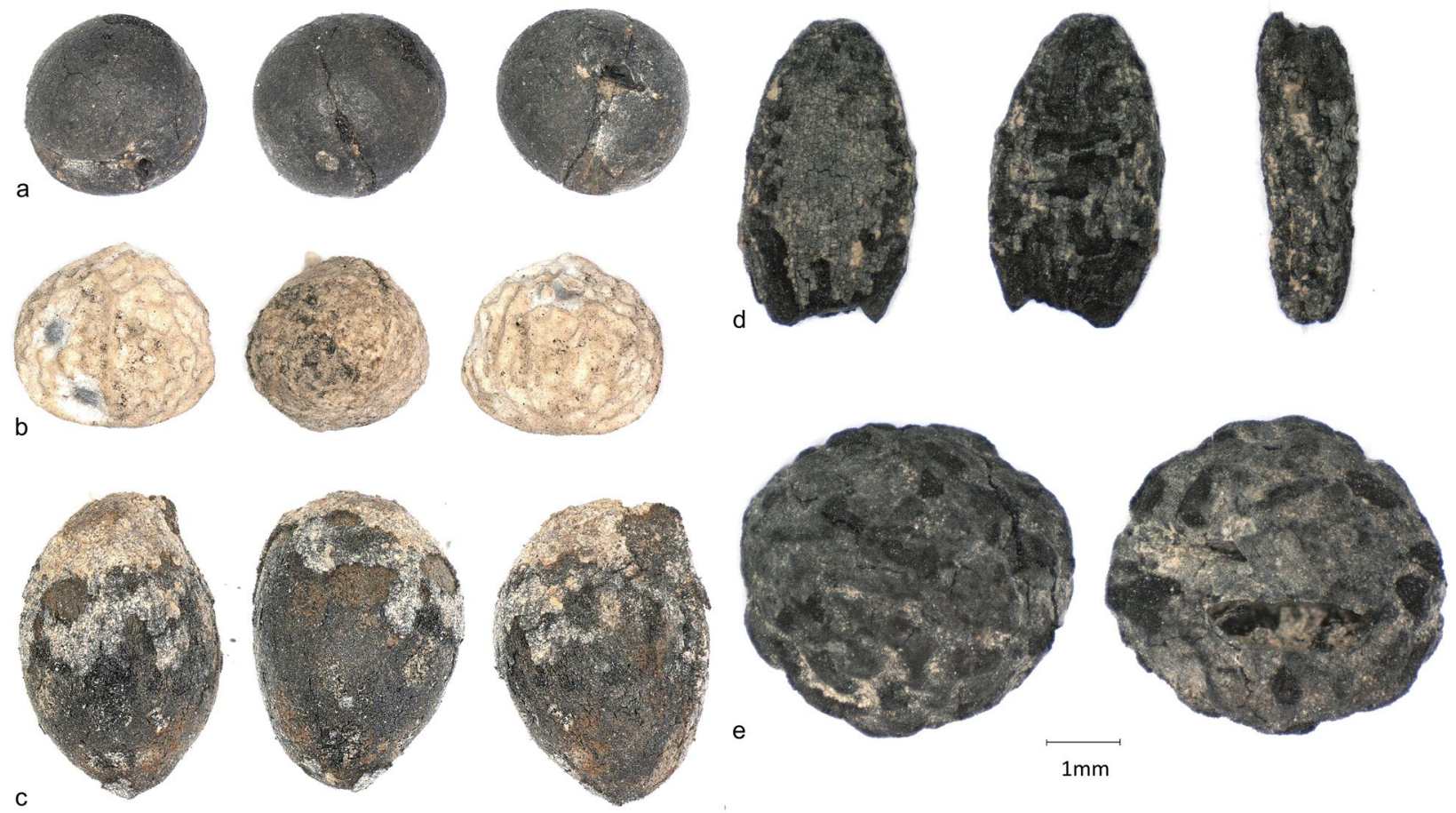

Fig. 3 A few key non-grain crops from the Barikot assemblage. a three views of a Pisum sativum; b mineralized Celtis caucasica fruitstone; c Gossypium sp. seed; $\mathbf{d}$ the single possible cucurbit seed from the assemblage; $\mathbf{e}$ Ziziphus nummularia fruitstone

Of the 5,350 grains and legumes, the most dominant crop in the assemblage was Hordeum (barley) $(n=2,235)$. It appeared to be primarily $H$. vulgare var. vulgare (a hulled six-rowed form), which is typically found in Central and South Asia for this time period (Spengler 2015). Some naked barley morphotypes may have been present, but we did not systematically quantify them. There were also 410 Triticum (wheat) grains, which all appeared to be a freethreshing form-presumably T. aestivum ssp. aestivum (bread wheat). Some of these were highly compact, similar to modern sphaerococcoid types, but, as with most wheat landraces, a wide range of variation was present. The wheats mostly appeared to be hexaploid, but there were a few that might be tetraploid durum wheats. As crops spread north from India and northeast from the Iranian plateau into Central Asia, the hulled wheats were left behind, although, $T$. turgidum ssp. durum (free-threshing tetraploid wheat) from the 3rd millennium BCE has been reported from Kashmir (Stevens et al. 2016). Therefore, the possibility should be considered that the few morphologically distinct grains from Barikot could be from glume wheats.

The lack of millets in the assemblage is most likely a result of the coarse sieve meshes used during recovery in the field, although future research will possibly modify this assumption. There were also 1,406 Oryza sativa (rice) grains, which varied immensely in morphology and range from elongated to compact, but mostly overlapped with measurements for $O$. sativa ssp. japonica (Chen et al. 2020). The most prominent legume is Lens culinaris (lentil). There were 678 lentils or lentil fragments that were intact enough to clearly differentiate them from other legume crops. There were also 287 Pisum sativum (pea) or pea fragments and $60 \mathrm{cf}$. Vicia sativa (vetch/pea). The possible V. sativa seeds can either represent minor secondary crops or weeds in cultivated fields; it is also possible that they are simply immature or underdeveloped peas. Three possible Vicia ervilia (bitter vetch) might also be immature peas. There were 150 seeds of Vigna mungo/radiata (mung beans or black gram); in this study, we did not attempt to differentiate between different species of cultivated Vigna. There were also 64 Macrotyloma uniflorum (horse gram) and two Lathyrus sativus (grass pea). No legume fragments resembled Cicer arietinum (chickpea). A single cf. Linum sp. (possible flax) seed was recovered from Sample 2016.121; an unidentified large legume was recovered from 2016.118 and a few cf. Avena sp. (possible oat) were recovered, but they may have been field weeds.

Collectively, there were nine clearly domesticated field crops in the assemblage and an additional four possible minor crops or wild relatives that were not morphologically distinct enough for reliable identification. In addition, Vitis vinifera was cultivated. The Ziziphus nummularia fruitstones, Juglans regia and Prunus cf. armeniaca nutshell fragments may represent cultivation of local trees, or 
they may represent the collection of wild resources. This is a diversity of crops and intensity of agricultural systems unlike anything that has been identified at any archaeological site further north in Central Asia at this time. Many of these crops, notably the warm-weather legumes, are absent from archaeobotanical results from Central Asia, but they are present further south in the Indus valley. The lack of many of these crops further north is likely connected to ecological limitations; legumes, such as Pisum sativum and Lens culinaris, which are more cold tolerant, spread into Central Asia earlier than other legumes. Likewise, many of these crops, notably Oryza sativa and Gossypium sp., are extremely water demanding and would have required irrigation, as they are traditionally grown in wet fields in this region.

\section{Agricultural diversification}

The earliest cultivation system to spread into these valleys and across northern India and Pakistan relied on cereals, notably Triticum aestivum and both naked and hulled forms of Hordeum vulgare, possibly also emmer and free-threshing tetraploid wheat (Fuller 2002; Salunkhe et al. 2012; Stevens et al. 2016). In addition to the cereals, other aspects of the southwest Asian repertoire arrived in northern India early, including Lens culinaris, Lathyrus sativa, Pisum sativum and Cicer arietinum, as well as sheep, goat and zebu cattle (Stevens et al. 2016; Petrie and Bates 2017; Bates 2020). Cereal crops arrived in the Bolan pass in Balochistan at the sites of Mehrgarh by 5000 BCE (Costantini 2008), Mundigak in Afghanistan around the same time, Sheri Khan Tarakai by 4000 BCE (Thomas and Cartwright 2010), and on the upper Punjab plain by 2500 BCE (Vishnu-Mittre 1972; Saraswat 1986; Saraswat and Pokharia 2003; Fuller 2006; Stevens et al. 2016). Liu et al. (2016) recently published direct dates from Hordeum vulgare grains at Damdama (2500-2400 BCE) and Lahuradewa (2300-2000 вСE), both on the Ganges plain (Saraswat 2005) and from sites along the Indus dating to 2850-2450 вСE. Both Triticum aestivum and T. turgidum ssp. dicoccum have been reported from sites in northern India and Kashmir (Lone et al. 1993; Fuller 2002; Salunkhe et al. 2012). As these cereals spread further north and east, the glume wheats were grown less and there is currently no evidence for T. turgidum in Central Asia until the Islamic period (see discussion in Spengler et al. 2018). Farmers integrated other southwest Asian crops into the cultivation system in Kashmir, including Lens culinaris and Pisum sativum (Saraswat and Pokharia 2003).

The Swat and Kashmir valleys are corridors of exchange and communication through the Hindu Kush mountains and they have dense archaeological remains, including farming village sites that date back to roughly $2500 \mathrm{cal}$ вСE (Vidale and Olivieri 2002; Bandey 2009). Historically, the Jhelum river valley in Baramulla District served as a key corridor connecting the Kashmir valley to Punjab. Interestingly, this region has many rivers and can easily provide irrigation, but it sits in a rain shadow outside the effects of the Indian summer monsoons. At this time in Kashmir, the southwest Asian crops were grown together with crops that were domesticated in India, such as Vigna mungo and V. radiata (Saraswat 1986; Saraswat and Pokharia 2003; Fuller 2006; Stevens et al. 2016). Archaeologists have argued that occupation and farming intensified in the Swat valley in the 2nd millennium $\mathrm{BCE}$, and geometric rock art depictions have been interpreted as field cultivation scenes (Vidale and Olivieri 2002; Vidale et al. 2011).

Archaeologists have noted that early sedentary occupation in northern India and Pakistan is culturally distinct from that of the Indus valley and further south (Mani 2008). Much of the current interpretation of what this cultural system looked like comes from the sites of Burzahom and Gufkral in Kashmir (ca. 3000-1500 BCE), where cereal grains and sheep and goat bones were recovered (Sharma 2000, 2013; Bandey 2009). Oryza sativa and Prunus fruitstones, likely almonds, have been reported in the archaeobotanical assemblages from the later phases at these sites dating between 1800-1000 вСе (Kajale 1982; Lone et al. 1993). Although Pokharia et al. (2018) do note that there is some question about the exact stratigraphic context of the Oryza sativa grains, they do mention directly dated $T$. aestivum (2290-2051 cal вСE) and $H$. vulgare (2467-2236 cal вСЕ) grains from Kanishkapura (Kanispur). Other southwest Asian crops appear to have spread into Kashmir at this time as well, attested by the finds of T. turgidum ssp. dicoccum, Lens culinaris, Lathyrus sativa, Pisum sativum and Vicia sativa from Kanispur. A later occupation layer at Kanispur, between 100 and $300 \mathrm{CE}$, showed that East Asian millets, Panicum miliaceum and Setaria italica (and possibly Echinochloa sp.), as well as Oryza sativa, had spread into the region by this period (Mani 2008). The site of Qasim Bagh, in the same area, provided direct dates on wheat and millet grains spanning 1800 to 1400 вСЕ (Spate et al. 2017). The site is located at about $1,500 \mathrm{~m}$, tucked into the Kashmir valley with the Himalaya to the east and the Pir Panjal mountains to the west. Also, single specimens each of Vitis vinifera and Sesamum indicum, and two specimens each of Linum usitatissimum and Macrotyloma uniflorum collectively indicate the increasing diversity in cultivated crops through time (Pokharia et al. 2018).

While this paper is primarily focused on the ancient connected cultural realm of the Swat and Kashmir valleys, it is important to acknowledge the interconnected nature of the broader region. Archaeobotanical research on the northern Ganges plain, from cultural contexts spanning 2500-200 BCE, has led to the identification of many of the same domesticated crops as we see in the Barikot assemblage. Ancient farming systems along the Indus utilized an astonishing 
Table 2 Summary of crop introductions and geographical areas of origin, covering southern Central and South Asia from the 3rd millennium $\mathrm{BCE}$ to the 1 st millennium CE

\begin{tabular}{|c|c|c|c|c|c|c|c|c|c|c|c|c|c|c|c|c|}
\hline \multirow[b]{2}{*}{ Origin/taxa } & \multicolumn{4}{|c|}{ 3rd mill. BCE } & \multicolumn{4}{|c|}{ 2nd mill. BCE } & \multicolumn{4}{|c|}{ 1st mill. BCE } & \multicolumn{4}{|c|}{ 1st mill. CE } \\
\hline & 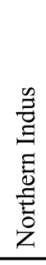 & 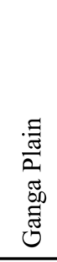 & 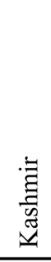 & 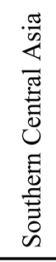 & 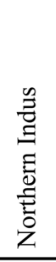 & 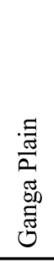 & 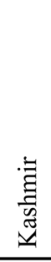 & 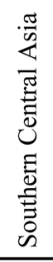 & 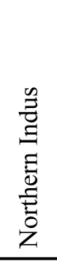 & 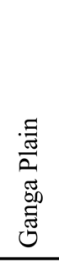 & 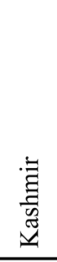 & 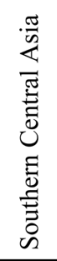 & 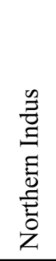 & 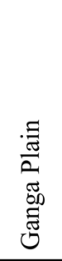 & 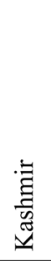 & 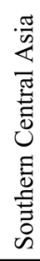 \\
\hline \multicolumn{17}{|l|}{ Southwest Asia } \\
\hline Hordeum vulgare & $\mathrm{X}$ & $\mathrm{X}$ & $\mathrm{X}$ & $\mathrm{X}$ & $\mathrm{X}$ & $\mathrm{X}$ & $\mathrm{X}$ & $\mathrm{X}$ & $\mathrm{X}$ & $\mathrm{X}$ & $\mathrm{X}$ & $\mathrm{X}$ & $\mathrm{X}$ & $\mathrm{X}$ & $\mathrm{X}$ & $\mathrm{X}$ \\
\hline Triticum aestivum & $\mathrm{X}$ & $\mathrm{X}$ & $\mathrm{X}$ & $\mathrm{X}$ & $\mathrm{X}$ & $\mathrm{X}$ & $\mathrm{X}$ & $\mathrm{X}$ & $\mathrm{X}$ & $\mathrm{X}$ & $\mathrm{X}$ & $\mathrm{X}$ & $\mathrm{X}$ & $\mathrm{X}$ & $\mathrm{X}$ & $\mathrm{X}$ \\
\hline T. aestivum (compact) & $\mathrm{X}$ & $\mathrm{X}$ & $\mathrm{X}$ & $\mathrm{X}$ & $X$ & $\mathrm{X}$ & $\mathrm{X}$ & $\mathrm{X}$ & $\mathrm{X}$ & $\mathrm{X}$ & $\mathrm{X}$ & $\mathrm{X}$ & $\mathrm{X}$ & $\mathrm{X}$ & $\mathrm{X}$ & $\mathrm{X}$ \\
\hline Lens culinaris & $\mathrm{X}$ & $\mathrm{X}$ & $\mathrm{X}$ & $\mathrm{X}$ & $\mathrm{X}$ & $\mathrm{X}$ & $\mathrm{X}$ & $\mathrm{X}$ & $\mathrm{X}$ & $\mathrm{X}$ & $\mathrm{X}$ & $\mathrm{X}$ & $\mathrm{X}$ & $\mathrm{X}$ & $\mathrm{X}$ & $\mathrm{X}$ \\
\hline Pisum sativum & $\mathrm{X}$ & $\mathrm{X}$ & $\mathrm{X}$ & $\mathrm{X}$ & $X$ & $\mathrm{X}$ & $\mathrm{X}$ & $\mathrm{X}$ & $\mathrm{X}$ & $\mathrm{X}$ & $\mathrm{X}$ & $\mathrm{X}$ & $\mathrm{X}$ & $\mathrm{X}$ & $\mathrm{X}$ & $\mathrm{X}$ \\
\hline Lathyrus sativum & & $\mathrm{X}$ & $\mathrm{X}$ & & $\mathrm{X}$ & $\mathrm{X}$ & $\mathrm{X}$ & $\mathrm{X}$ & $\mathrm{X}$ & $\mathrm{X}$ & $\mathrm{X}$ & $\mathrm{X}$ & $\mathrm{X}$ & $\mathrm{X}$ & $\mathrm{X}$ & $\mathrm{X}$ \\
\hline Cicer arietinum & & & & & $\mathrm{X}$ & $\mathrm{X}$ & & $\mathrm{X}$ & $\mathrm{X}$ & $\mathrm{X}$ & & $\mathrm{X}$ & $\mathrm{X}$ & $\mathrm{X}$ & & $\mathrm{X}$ \\
\hline Vicia spp. & & $\mathrm{X}$ & & & $\mathrm{X}$ & $\mathrm{X}$ & & $\mathrm{X}$ & $\mathrm{X}$ & $\mathrm{X}$ & & $\mathrm{X}$ & $\mathrm{X}$ & $\mathrm{X}$ & & $\mathrm{X}$ \\
\hline Linum usitatissimum & $\mathrm{X}$ & $\mathrm{X}$ & & & $\mathrm{X}$ & & & $\mathrm{X}$ & $\mathrm{X}$ & $\mathrm{X}$ & & $\mathrm{X}$ & $\mathrm{X}$ & & & $\mathrm{X}$ \\
\hline \multicolumn{17}{|l|}{ East Asia } \\
\hline Oryza sativa & $\mathrm{X}$ & $\mathrm{X}$ & & & $\mathrm{X}$ & $\mathrm{X}$ & $\mathrm{X}$ & & $\mathrm{X}$ & $\mathrm{X}$ & $\mathrm{X}$ & & $\mathrm{X}$ & $\mathrm{X}$ & $\mathrm{X}$ & $\mathrm{X}$ \\
\hline Panicum miliaceum & & & & & $\mathrm{X}$ & & $\mathrm{X}$ & $\mathrm{X}$ & $\mathrm{X}$ & $\mathrm{X}$ & $\mathrm{X}$ & $\mathrm{X}$ & $\mathrm{X}$ & $\mathrm{X}$ & $\mathrm{X}$ & $\mathrm{X}$ \\
\hline Setaria italica & & & & & $\mathrm{X}$ & & & & $\mathrm{X}$ & $\mathrm{X}$ & & $\mathrm{X}$ & $\mathrm{X}$ & $\mathrm{X}$ & & $\mathrm{X}$ \\
\hline Cannabis sativa & & & & & $\mathrm{X}$ & $\mathrm{X}$ & & & $\mathrm{X}$ & $\mathrm{X}$ & & & $\mathrm{X}$ & $\mathrm{X}$ & & \\
\hline \multicolumn{17}{|l|}{ South Asia } \\
\hline Oryza sativa & $\mathrm{X}$ & $\mathrm{X}$ & & & $\mathrm{X}$ & $\mathrm{X}$ & $\mathrm{X}$ & & $\mathrm{X}$ & $\mathrm{X}$ & $X$ & & $\mathrm{X}$ & $\mathrm{X}$ & $\mathrm{X}$ & $\mathrm{X}$ \\
\hline Brachiaria ramosa & & & & & $\mathrm{X}$ & & & & $\mathrm{X}$ & & & & $\mathrm{X}$ & & & \\
\hline Panicum sumatrense & & & & & $\mathrm{X}$ & & & & $\mathrm{X}$ & & & & $\mathrm{X}$ & & & \\
\hline Setaria pumila & & & & & $\mathrm{X}$ & & & & $\mathrm{X}$ & & & & $\mathrm{X}$ & & & \\
\hline $\begin{array}{l}\text { Paspalum } \\
\text { scrobiculatum }\end{array}$ & & $\mathrm{X}$ & & & $\mathrm{X}$ & $\mathrm{X}$ & & & $\mathrm{X}$ & $\mathrm{X}$ & & & $\mathrm{x}$ & $\mathrm{X}$ & & \\
\hline Macrotyloma uniflorum & & & & & $\mathrm{X}$ & $\mathrm{X}$ & & & $\mathrm{X}$ & $\mathrm{X}$ & & & $\mathrm{X}$ & $\mathrm{X}$ & & \\
\hline Vigna spp. & & $\mathrm{X}$ & & & $\mathrm{X}$ & $\mathrm{X}$ & & & $\mathrm{X}$ & $\mathrm{X}$ & & & $\mathrm{X}$ & $\mathrm{X}$ & & \\
\hline Sesamum indicum & & & & & $\mathrm{X}$ & $\mathrm{X}$ & $\mathrm{X}$ & & $\mathrm{X}$ & $\mathrm{X}$ & $\mathrm{X}$ & & $\mathrm{X}$ & $\mathrm{X}$ & $\mathrm{X}$ & \\
\hline Gossypium sp. & & $\mathrm{X}$ & & & $\mathrm{X}$ & & & & $\mathrm{X}$ & $\mathrm{X}$ & & $\mathrm{X}$ & $\mathrm{X}$ & & & \\
\hline Cucumis melo/sativa & & & & & $\mathrm{X}$ & & & & $\mathrm{X}$ & $\mathrm{X}$ & & & $\mathrm{X}$ & & & \\
\hline \multicolumn{17}{|l|}{ North Africa } \\
\hline Eleusine coracana & & & & & $\mathrm{X}$ & $\mathrm{X}$ & $\mathrm{X}$ & & $\mathrm{X}$ & $\mathrm{X}$ & $\mathrm{X}$ & & $\mathrm{X}$ & $\mathrm{X}$ & $\mathrm{X}$ & \\
\hline Sorghum bicolor & & & & & $\mathrm{X}$ & $\mathrm{X}$ & & & $\mathrm{X}$ & $\mathrm{X}$ & & & $\mathrm{X}$ & $\mathrm{X}$ & & \\
\hline Pennisetum glaucum & & & & & $\mathrm{X}$ & & & & $\mathrm{X}$ & $\mathrm{X}$ & & & $\mathrm{X}$ & & & \\
\hline Citrullus lanatus & & & & & $\mathrm{X}$ & & & & $\mathrm{X}$ & $\mathrm{X}$ & & & $\mathrm{X}$ & & & \\
\hline Carthamus tinctorius & & & & & $\mathrm{X}$ & & & & $\mathrm{X}$ & $\mathrm{X}$ & & & $\mathrm{X}$ & & & \\
\hline Brassica juncea & & & & & $\mathrm{X}$ & $\mathrm{X}$ & & & $\mathrm{X}$ & $\mathrm{X}$ & & & $\mathrm{X}$ & $\mathrm{X}$ & & \\
\hline Allium sp. & & & & & $\mathrm{X}$ & & & & $\mathrm{X}$ & $\mathrm{X}$ & & & $\mathrm{X}$ & & & \\
\hline \multicolumn{17}{|l|}{ Arboreal } \\
\hline Vitis vinifera & $\mathrm{X}$ & & & $\mathrm{X}$ & $\mathrm{X}$ & $\mathrm{X}$ & $\mathrm{X}$ & $\mathrm{X}$ & $\mathrm{X}$ & $\mathrm{X}$ & $\mathrm{X}$ & $\mathrm{X}$ & $\mathrm{X}$ & $\mathrm{X}$ & $\mathrm{X}$ & $\mathrm{X}$ \\
\hline Phoenix dactylifera & & & & & $\mathrm{X}$ & & & & $\mathrm{X}$ & $\mathrm{X}$ & & & $\mathrm{X}$ & & & \\
\hline Ziziphus spp. & & $\mathrm{X}$ & & & $\mathrm{X}$ & $\mathrm{X}$ & & & $\mathrm{X}$ & $\mathrm{X}$ & & & $\mathrm{X}$ & $\mathrm{X}$ & & \\
\hline Prunus amygdalus & & & $\mathrm{X}$ & & $\mathrm{X}$ & & $\mathrm{X}$ & & $\mathrm{X}$ & & $\mathrm{X}$ & $\mathrm{X}$ & $\mathrm{X}$ & & $\mathrm{X}$ & \\
\hline Prunus persica & & & & & & & & & & & $\mathrm{X}$ & & $\mathrm{X}$ & $\mathrm{X}$ & $\mathrm{X}$ & $\mathrm{X}$ \\
\hline Prunus armeniaca & & & & & & & & & & & $\mathrm{X}$ & & $\mathrm{X}$ & $\mathrm{X}$ & $\mathrm{X}$ & $\mathrm{X}$ \\
\hline Juglans regia & & & $\mathrm{X}$ & & $\mathrm{X}$ & & $\mathrm{X}$ & & $\mathrm{X}$ & & $\mathrm{X}$ & $\mathrm{x}$ & $\mathrm{X}$ & & $\mathrm{X}$ & \\
\hline
\end{tabular}

array of crops, arguably a greater diversity than anywhere else in the ancient world (Weber 1991, 1999; Fuller and Madella 2002). Pokharia et al. (2017) summarized archaeobotanical remains from the sites of Hetapatti (ca. 2500-1500
ВСE), Raja-Nal-ka-Tila (са. 1300-700 вСE), and Rajdhani (са. 800-200 вСЕ). The abundant archaeobotanical data from the Indus region was recently synthesized by Bates (2019), although many other syntheses have been presented 
(Table 2; for example, Misra and Kajale 2003; Weber and Fuller 2008; Pokharia et al. 2014). Several studies have also illustrated shifting preference for millets over time, from primarily Eleusine sp. in the Mature Harappan to a mix of Eleusine sp., Setaria sp. and Panicum sp. in the Later Harappan (Reddy 2003). Table 2 illustrates a gradual process of increasing crop diversification through time, as crops from different regions spread into northern South Asia and cultivation systems expanded to incorporate them.

There have been a handful of archaeobotanical studies of the Kushan period, ca. in the first 300 years CE, after organized trade routes and reliable markets were fully established across inner Asia (for instance, Pokharia and Saraswat 1999). As an example, biological remains from a trench in the northeastern part of the Balaji temple at Naimisharanya, in Sitapur District of Uttar Pradesh, illustrate that there was a complex cultivation system. As in other areas of Central Asia at this time, barley continued to dominate the cultivation system (Srivastava and Tewari 2011) and both hulled and naked forms were present - likely all six-rowed (Saraswat 1980, 1992). Four types of pulses were also reported from Naimisharanya (Srivastava and Tewari 2011). While Echinochloa crus-galli is a common agricultural weed, it was also grown as a crop in parts of Central Asia, likewise, seeds of Vicia sativa at the site could either represent a minor legume crop or weeds in winter crop fields. Interestingly, ancient remains of Azadirachta indica (neem) fruits were also recovered from Naimisharanya (Srivastava and Tewari 2011).

\section{The cultivation system}

\section{Water-demanding crops}

Much of northern Pakistan lies in the rain shadow of the Pamirs and receives limited precipitation, with the majority coming during the winter months. The cultivation of waterintensive crops would have required ways of managing water resources. In exploring the prominence of crops such as Gossypium sp. and Oryza sativa, we can understand better the labour investment needed in farming. Additionally, T. aestivum and most legumes can be water-demanding if they are grown in open fields rather than small gardens.

Traditionally, rice cultivation across West Asia relied on wet paddy fields; but in some cases, this highly waterdemanding crop is/was grown in very arid regions. By the late medieval period, it appears to have been present across West Asia (Spengler 2019; Chen et al. 2020). Understanding the role of rice in the cultivation system of the Swat valley helps illustrate how the crop rose to significance across areas further north and west, despite the evident ecological constraints. The origins and timing of its cultivation in South Asia and the process of hybridization between East and South Asian rice varieties have been topics of debate for roughly a decade (such as Fuller and Madella 2002; Fuller 2005, 2006, 2011; Saraswat 2005; Tewari et al. 2008; Fuller et al. 2010; Petrie et al. 2016). There is evidence for people collecting wild $O$. sativa across northern India for several millennia before the introduction of East Asian domesticated $O$. sativa ssp. japonica (Saraswat 2004, 2005; Pokharia et al. 2017). While there is a considerable range of morphological variability among $O$. sativa grains from Barikot, and there is a significant range of overlap between $O$. sativa ssp. indica and ssp. japonica, the Barikot grains are generally more compact, resembling more closely ssp. japonica. Following this rule of thumb, the $O$. sativa at Barikot, like early examples of rice in the southern Himalaya and Central Asia, may have had East and not South Asian origins (Chen et al. 2020). Vidale et al. (2011) suggest that East Asian rice originally dispersed into northwest India through the mountain passes, referencing early $O$. sativa in pottery impressions reported by Costantini (1987). The prominence of rice in the Indus valley seems to have largely arisen after the introduction of East Asian varieties, which hybridized with local cultivated $O$. sativa (Stevens et al. 2016). For example, at the site of Hetapatti, on the Ganges plain, in the 2nd millennium вСE, Hordeum vulgare is the dominant crop, but by the 1st millennium BCE at the site of Rajdhani, rice grains are 250 times more abundant than barley (Pokharia et al. 2017).

Gossypium arboreum/herbaceum is a second waterdemanding crop recovered from Barikot, with a total of 49 seeds identified. While Gossypium production in most of Central Asia and India is for commercial purposes today and therefore extremely water demanding, cotton growing was originally for small-scale consumption. Hirth (2009) notes that small-scale Gossypium cultivation for domestic craft production does not require major water or labour inputs. Most reports of early Gossypium remains from archaeological sites prior to large-scale irrigation and organized cultivation strategies in the medieval period, are restricted to the moist tropical or semitropical zones of South Asia (Brubaker et al. 1999). The dispersal of Gossypium into more northern regions is often linked to the Islamic Green Revolution (Watson 1983), and there may have been photoperiod sensitivity constraints to its northern dispersal (Brite and Marston 2013). The Barikot Gossypium sp. illustrates that cotton at least started dispersing north well before the Islamic period. Likewise, Brite and Marston (2013) report Gossypium sp. seeds from Kara-tepe in Uzbekistan dating to 300-500 CE. Interestingly, traces of Gossypium sp. fabric and threads were identified from inside two reliquaries from the Buddhist sanctuary of Butkara I in Swat, roughly $20 \mathrm{~km}$ north of Barikot, belonging to a first and second century $\mathrm{CE}$ archaeological context (Costantini et al. 2002). Gossypium 
sp. was clearly a prominent crop across the Indus region from the mid 3rd millennium BCE onwards (Fuller 2008; Bouchaud et al. 2011).

\section{Crop rotation cycles}

South Asia, broadly speaking, provides an exceptional region for studying human adaptation to variable and dynamic environments. Within the area of northern India and Pakistan there are widely differing rainfall patterns, with some areas receiving summer monsoonal rains and others better suited for sowing in autumn (Petrie et al. 2016, 2017; Petrie and Bates 2017). A myriad of possible ancient cultivation strategies have been proposed to accompany these differing ecological constraints (Fuller 2011; Kingwell-Banham et al. 2015). Botanical investigations at the site of Rojdi, led by Weber $(1991,1999)$ suggest that many of the summer crops were millets, Eleusine sp., Panicum sumatrense, Setaria pumila and S. italica. Similarly, work at Harappa has led to discussions of the nature of crop rotation cycles in the Indus valley (Weber 2003). Recently, Petrie and Bates (2017) synthesized this extensive body of literature, further illustrating how complex northern Indian cultivation systems were. The site of Barikot is located in a winter rainfall zone in the rain shadow of the Pamirs, leading to unique cultivation conditions and the ability to grow warm weather crops further north than usual.

The intensification of agricultural strategies appears to be directly connected with trans-Eurasian crop exchange (Fuller and Boivin 2009; Spengler 2019). For example, Pokharia et al. (2018) and Lone et al. (1993) suggested that the presence of East Asian millets and rice in Kashmir may represent cereal farming in two seasons, with millet sown in spring and harvested in the dry season. Miller et al. (2016) suggest that the adoption of East Asian millets in urban contexts across Central and southwest Asia may represent the introduction of summer crops into a previously winter crop system. This argument is supported by the almost complete lack of millets in big urban centres until the early 1st millennium BCE, whereas they were prominent in the foothills of Central Asia for millennia before then, likely linked to low investment rain-fed farming. Secondary crops often play key roles in crop rotation systems, notably as summer vegetables, legumes, or oil and fibre crops (Sherratt 1983). Oryza sativa was undoubtedly an important summer crop at Barikot; additionally, a few of the South Asian legumes could have been summer crops, including Vigna mungo/ radiata and Macrotyloma uniflorum. Pisum sativum and Lens culinaris are grown most extensively in cool climates, either at high altitudes in South Asia or as winter crops in some hotter regions. The prominent summer crops across the more arid regions of southwest and Central Asia include the East Asian millets, which were not identified at Barikot, either illustrating a largely winter crop-based cultivation system or a loss of data due to the coarse sieve. The unique geography of the Swat valley makes it particularly suitable for a double cropping system with wet and dry season crops sown on the same plot of land in spring and autumn, that was developed at much lower elevations and latitudes. Notably there is high thermal insulation in the valley, because of its unusual East-West orientation, seen in a few other valleys in this region, including Baghlan and Kapisa on the two sides of the Hindu Kush and the Nangarhar, Manshera, Kashmir, and possibly the valley of Almora (Uttarakhand) to the south of the Karakoram Himalayas. These are all examples of what has been defined by one of the authors as "double-crop economic pocket zones" as river valleys particularly good for farming, where mild conditions allow South Asian crops to be grown further north than usual and for two crops per year on a plot of land (Olivieri 2021). In this regard, drought tolerant crops, such as the millets, were less important, and rice played a more prominent role at Barikot.

According to Lone et al. (1993), the East Asian millets arrived late to the southern Himalayan rim and northern India, Panicum miliaceum at ca 100 всE and Setaria italica at $250 \mathrm{CE}$, although Spate et al. (2017) recently pushed those dates back to the early 2nd millennium BCE with the discovery of millet at Qasim Bagh. Setaria italica is well attested in the Indus valley by the late Harappan period (ca. 2000 вСE), at Surkotada, Ojiyana, and Hulas (cf. Fuller 2003, 2006; Pokharia 2007), and it increases in prominence at later sites (Petrie and Bates 2017; Bates 2019). The dispersal of East Asian millets through the inner Asian mountain corridor is well known (Spengler 2019). However, a secondary spread of East Asian cultural traits into northern India and Pakistan during the early 2nd millennium BCE is also recognized. Fuller and Boivin (2009) note the appearance of Cannabis sativa, East Asian Oryza sativa, Prunus persica (peach), and $P$. armeniaca (apricot) in northern India as signs of a "Chinese horizon", signs of influence from the northeast. This is present in the valleys of Kashmir and Swat by 1800 BCE (Lone et al. 1993; Stevens et al. 2016). Finds of harvesting knives, jade and other stone objects, and tripod ceramic vessels are all signs of cultural dispersal from the northeast (Fairservis 1975; Stacul 1976, 1993; Sharif and Thapar 1992; Han 2012; Coningham and Young 2015).

\section{Arboriculture}

Understanding the process of domestication of fruit and nut trees, long-generation perennials, can also provide much information on concepts of land tenure and investment in future generations. It can also inform on scheduling in the economy, resource protection practices, mobility and exchange. It is clear that people have been collecting fruits and nuts from the once-wooded foothills of Central Eurasia 
for millennia (Spengler and Willcox 2013); however, we know little about when people started actively maintaining these trees and breeding them. In the northern Indus valley during the 2nd millennium BCE, the cultivation of long-lived perennials is indicated by archaeobotanical remains of Vitis vinifera, Gossypium arboreum (tree cotton), Phoenix dactylifera (date palm), and Ziziphus spp. (Fuller and Madella 2002; Bates 2020). Slightly later, Prunus persica and $P$. armeniaca were introduced to the Indus valley; although neither grows particularly well in such hot moist regions. Further south in India, a much wider variety of fruit trees has been archaeobotanically identified by the mid 2nd millennium BCE; however, most of these would not have been productive further north, including Artocarpus heterophyllus (jackfruit), Mangifera indica (mango), and Citrus spp. (oranges, lemons etc.) (Fuller 2009; Stevens et al. 2016).

Most of the fruit and nut remains recovered in the Barikot study represent plants that would have grown wild in the foothills, making it impossible to determine to what degree people were cultivating, maintaining, or manipulating them. Only 25 Vitis vinifera pips were recovered from Barikot, but grapes are far less likely to be carbonized than parched cereal grains, especially if the seeds were removed during wine making. Grapes are the best represented fruit of ancient Central Asia, and they played a prominent role in the economy of people in the foothills and desert oases for at least three millennia (Spengler 2019). Miller (2008) discusses the early appearance of viticulture in the Kopet Dag mountains of Turkmenistan, roughly four millennia ago, and Spengler et al. (2017) discuss the spread of Vitis into the northern foothills by two and a half millennia ago. A single grape pip from Qasim Bagh (Spate et al. 2017) and two from Loebanr III (ca. 1700-1400 BCE) were recovered (Costantini 1987). Vitis pips are also found from sites across the Indus valley dating back to the early Harappan period (Bates 2019). Wine making in Swat is archaeologically confirmed by at least as early as the early 1 st millennium $\mathrm{CE}$, through the discovery of several wine presses, particularly the area of Barikot (Olivieri et al. 2006), as well as several pottery devices for distillation at Barikot (Allchin 1979) and by textual evidence (Falk 2009).

Ziziphus nummularia and Z. mauritiana are both found at sites across northern India and Pakistan, especially in more arid regions (Bates 2019; Pokharia et al. 2017). A specific small-fruited morphotype of Z. nummularia grows wild throughout the hills of the Swat valley (Ahmad et al. 2011). Therefore, the small Ziziphus fruitstones that we recovered at Barikot may have been collected from the wild. Alternatively, Ziziphus trees are often planted at field edges and only lightly maintained; they often mark boundaries or protect fields, while also providing fruit. It is likely that low investment maintenance of this long-generation perennial was practised by the occupants of Barikot. Similarly, Juglans regia (walnut) woods once covered much of the southern Central Asian foothills; however, these trees were eventually cultivated and the wild stands were lost. Pleistocene deposits at Karewa in Kashmir illustrate how long the walnuts have been present in the mountain foothills and that people have been collecting the nuts for tens of thousands of years (Vishnu-Mittre 1965, 1984). Juglans regia and Prunus dulcis (almond) nutshells were also recovered from Kanispur (3000-2000 вСE), illustrating a long history of human use in the region (Pokharia et al. 2018). It is likely that these trees were planted and maintained near the settlement in the Swat valley. It is also possible that the 14 Celtis caucasica seeds and small fragments of nutshell all represent either foraging in the wild or the maintenance of such useful trees near the settlement. Ultimately, none of the arboreal seed/ fruit remains recovered at Barikot definitively indicate the cultivation of trees. However, the possibility that people were loosely maintaining and manipulating the populations of Ziziphus and Juglans regia trees in spaces between fields is highly likely. This likelihood is further supported by the evidence of viticulture, showing that the population was already familiar with perennial crops.

\section{Conclusions}

The Barikot settlement site is located in the Swat valley of northern Pakistan and it was occupied during the 1st millennium BCE. Historically the valley represented a key pass through the mountains, and these biologically diverse passes where arable farming was possible were areas of human settlement for millennia. The archaeobotanical evidence that we present here shows the complex agricultural practices that were underway in the high mountain pass in a semi-arid ecological zone three millennia ago. The farmers at the site undoubtedly used some form of irrigation or water channelling in order to maintain water-demanding crops in the rain shadow of the Pamirs. Crops, such as Oryza sativa and Gossypium sp., are particularly water-demanding and would have required great labour and time investments. However Gossypium sp. can be grown on a smaller scale in restricted field plots and therefore requires less water input than modern industrial cotton production. Additionally, simple irrigation is particularly easy in mountain valleys with steep slopes and steady glacial melt streams in the summer which can be diverted for this purpose.

The Barikot data help link the archaeobotany of South and Central Asia, allowing further understanding of the processes of crop exchange across the ancient world. The farmers at Barikot grew crops that originally came from central East Asia (O. sativa ssp. japonica), southwest Asia (cereals and legumes), and central South Asia (legumes). These farmers brought together crops that had evolved in 
different ecological settings and were adapted to different ecological conditions. Due to the particular evolutionary courses of the progenitors for these crops and their different growing habits, all of these crops required specific growing practices. This allowed for the formation of complex seasonal cycles of agriculture, and several summer legumes and rice appear to have complemented winter wheat and barley. Furthermore, there is reason to believe that some limited maintenance of trees for fruits and nuts was practised, although all of the identified ones represent local taxa. The Barikot archaeobotanical assemblage illustrates how complex and regionally specific cultivation practices were across South Asia. This study also adds to our understanding of the prominent role of the river valleys, and "double-crop pocket zones", across the Pamirs, Hindu Kush and southern Himalaya in the spread of crops and cultivation technology.

Acknowledgements Research funds and support were provided by the Max Planck Institute for the Science of Human History and the European Research Council, grant number 851102, Fruits of Eurasia: Domestication and Dispersal (FEDD). We also thank the ISMEO team for excavating the site and collecting sediment samples. We are grateful to the Department of Archaeology and Museums, Government of Pakistan and the Directorate of Archaeology and Museums, Government of Khyber-Pakhtunkhwa for issuing the necessary permits.

Funding Open Access funding enabled and organized by Projekt DEAL.

Open Access This article is licensed under a Creative Commons Attribution 4.0 International License, which permits use, sharing, adaptation, distribution and reproduction in any medium or format, as long as you give appropriate credit to the original author(s) and the source, provide a link to the Creative Commons licence, and indicate if changes were made. The images or other third party material in this article are included in the article's Creative Commons licence, unless indicated otherwise in a credit line to the material. If material is not included in the article's Creative Commons licence and your intended use is not permitted by statutory regulation or exceeds the permitted use, you will need to obtain permission directly from the copyright holder. To view a copy of this licence, visit http://creativecommons.org/licenses/by/4.0/.

\section{References}

Ahmad I, Ibrar M, Barkatullah AN (2011) Ethnobotanical study of Tehsil Kabal, Swat District, KPK, Pakistan. J Bot 368572:1-9

Aldenderfer M, Eng JT (2016) Death and burial among two ancient high-altitude communities of Nepal. In: Robbins Schug G, Walimbe SR (eds) A companion to South Asia in the past. WileyBlackwell, New York, pp 374-397

Allchin FR (1979) India: the ancient home of distillation? Man 14:55-63

Bandey AA (2009) Prehistoric Kashmir: Archaeological history of Palaeolithic \& Neolithic cultures. Dilpreet Publishing House, New Delhi

Bates J (2019) The published archaeobotanical data from the Indus civilisation, South Asia, c. 3200-1500 BC. J Open Archaeol Data $7: 1-5$
Bates J (2020) Kitchen gardens, wild forage and tree fruits: a hypothesis on the role of the Zaid season in the Indus civilisation (c. 3200-1300 BCE). Archaeol Res Asia 21:100175

Baums S (2019) A survey of place-names in Gāndhārī inscriptions and a new oil lamp from Malakand. In: Rienjang W, Stewart P (eds) The geography of Gandhāran art. Archaeopress, Oxford, pp 167-174

Bouchaud C, Tengberg M, Dal Prà P (2011) Cotton cultivation and textile production in the Arabian Peninsula during antiquity; the evidence from Madâ'in Sâlih (Saudi Arabia) and Qal'at alBahrain (Bahrain). Veget Hist Archaeobot 20:405-417

Brite EB, Marston JM (2013) Environmental change, agricultural innovation, and the spread of cotton agriculture in the Old World. $\mathrm{J}$ Anthropol Archaeol 32:39-53

Brubaker CL, Bourland FM, Wendel JF (1999) The origin and domestication of cotton. In: Smith CW, Cothren JT (eds) Cotton: origin, history, technology, and production. Wiley, New York, pp 3-32

Callieri P, Colliva L, Micheli R et al (2000) Bīr-kot-ghwandai, Swat, Pakistan. 1998-1999 Excavation Report. East West 50:191-226

Cappers RTJ, Bekker RM (2012) A manual for the identification of plant seeds and fruits. Barkhuis, Groningen

Chen G, Xinying Z, Jianxin W et al (2020) Kushan period Rice in the Amu Darya basin: Evidence for prehistoric exchange along the southern Himalaya. Sci China Earth Sci 63:841-851

Coningham R, Young R (2015) The archaeology of South Asia: from the Indus to Asoka, ca. 6500 BCE-200 CE. Cambridge University Press, Cambridge

Costantini L (1987) Appendix B. Vegetal remains. In: Stacul G (ed) Prehistoric and protohistoric Swat, Pakistan, c. 3000-1400 BC (Reports and Memoirs 20). ISMEO, Rome, pp 155-165

Costantini L (2008) The first farmers in Western Pakistan: the evidence of the Neolithic agropastoral settlement of Mehrgarh. Pragdhara 18:167-178

Costantini L, Costantini Biasini L, Ferro D (2002) Sui contenuti di alcuni reliquiari da Butkara I e saidu Sharif I, Swat. In: Callieri P, Filligenzi A (eds) 11 Maestro di Saidu Sharif Alle origini dell'arte del Gandhara. IsMEO, Rome

Dhungel R (2002) The Kingdom of Lo (Mustang). A historical study. Tashi Gephel Foundation. Lusha Press, Kathmandu

Eng JT, Aldenderfer M (2017) Bioarchaeological profile of stress and dental disease among ancient high altitude Himalayan communities of Nepal. Am J Hum Biol 29:e22998

Fairservis W (1975) The roots of ancient India. The University of Chicago Press, Chicago

Falk H (2009) Making wine in Gandhara under Buddhist monastic supervision. Bull Asia Inst 23:65-78

Frachetti MD (2012) Multiregional emergence of mobile pastoralism and nonuniform institutional complexity across Eurasia. Curr Anthropol 53:2-38

Frachetti MD, Smith CE, Copp C (2018) Pastoralist participation (PastPart): a model of mobility and connectivity across the Inner Asian Mountain Corridor. In: Anemone RL, Conroy GC (eds) New geospatial approaches to the anthropological sciences. University of New Mexico Press, Albuquerque

Fritz GJ (2005) Palaeoethnobotanical methodology and applications. In: Maschner HG, Chippindale C (eds) Handbook of archaeological methods. Altamira Press, Lanham, pp 773-834

Fuller DQ (2002) Fifty years of archaeobotanical studies in India: laying a solid foundation. In: Settar S, Korisettar R (eds) Indian archaeology in retrospect. Archaeology and interactive disciplines, vol 3. Indian Council for Historical Research, New Delhi, pp 247-364

Fuller DQ (2003) Indus and non-Indus agricultural traditions: local developments and crop adoptions on the Indian Peninsula. In: Weber SA, Belcher WR (eds) Indus ethnobiology: new perspectives from the field. Lexington Books, Lanham, pp 343-396 
Fuller DQ (2005) Ceramics, seeds and culinary change in prehistoric India. Antiquity 79(306):761-777

Fuller DQ (2006) Agricultural origins and frontiers in South Asia: a working synthesis. J World Prehist 20:1-86

Fuller DQ (2008) The spread of textile production and textile crops in India beyond the Harappan zone: an aspect of the emergence of craft specialization and systematic trade. In: Osada T, Uesugi A (eds) Linguistics, archaeology, and the human past. Research Institute for Humanity and Nature, Kyoto, pp 1-26

Fuller DQ (2009) Recent lessons from Near Eastern archaeobotany: wild cereal use, pre-domestication cultivation and tracing multiple origins and dispersals. Pragdhara 18:105-134

Fuller DQ (2011) Finding plant domestication in the Indian subcontinent. Curr Anthropol 52:S347-S362

Fuller DQ, Boivin N (2009) Crops, cattle and commensals across the Indian Ocean: current and potential archaeobiological evidence. Études Océan Indien 42(43):13-46

Fuller DQ, Madella M (2002) Issues in Harappan archaeobotany: retrospect and prospect. In: Settar S, Korisettar R (eds) Indian archaeology in retrospect. Indian Council for Historical Research, New Delhi

Fuller DQ, Sato Y-I, Castillo C et al (2010) Consilience of genetics and archaeobotany in the entangled history of rice. J Archaeol Anthropol Sci 2:115-131

Gleba M, Vanden Berghe I, Aldenderfer M (2016) Textile technology in Nepal in the 5th-7th centuries CE: the case of Samdzong. STAR: Sci Technol Archaeol Res 2:25-35

Han J (2012) The painted pottery road and early Sino-Western cultural exchanges. Anabasis 3:25-42

Hirth K (2009) Craft production, household diversification, and domestic economy in prehispanic Mesoamerica. Archeol Pap Am Anthropol Assoc 19:13-32

Jeong C, Ozga AT, Witonsky DB et al (2016) Long-term genetic stability and a high-altitude East Asian origin for the peoples of the high valleys of the Himalayan arc. Proc Natl Acad Sci USA 113:7,485-7,490

Kajale MD (1982) First record of ancient grains at Naikund. In: Deo SB, Jamkhedkar AP (eds) Excavations at Naikund 1978-1980. Department of Archaeology and Museums, Mumbai, pp 60-63

Kingwell-Banham E, Petrie CA, Fuller DQ (2015) Early agriculture in South Asia. In: Barker G, Goucher C (eds) The Cambridge World history. Vol. 2, A world with agriculture, 12,000 BCE500 CE. Cambridge University Press, Cambridge, pp 261-288

Kuzmina EE (2008) The prehistory of the Silk Road. University of Pennsylvania Press, Philadelphia

Liu X, Lister DL, Zhao Z et al (2016) The virtues of small grain size: potential pathways to a distinguishing feature of Asian wheats. Quat Int 426:107-119

Lone FA, Khan M, Buth GM (1993) Palaeoethnobotany: plants and ancient man in Kashmir. Oxford \& IBH Publishing Company, Oxford

Mair V, Hoh E (2009) The true history of tea. Thames \& Hudson, London

Mani BR (2008) Kashmir Neolithic and early Harappan: a linkage. Pragdhara 18:229-247

Massa G, Aldenderfer M, Martinón-Torres M (2019) Of gold masks, bronze mirrors and brass bracelets: analyses of metallic artefacts from Samdzong, Upper Mustang, Nepal 450-650 CE. Archaeol Res Asia 18:68-81

Miller NF (2008) Sweeter than wine? The use of the grape in early western Asia. Antiquity 82:937-946

Miller NF, Spengler RN, Frachetti M (2016) Millet cultivation across Eurasia: Origins, spread, and the influence of seasonal climate. Holocene 26:1,566-1,575

Misra VN, Kajale MD (2003) Introduction of African crops into South Asia. Indian Society for Prehistoric and Quaternary Studies, Pune
Motuzaite Matuzeviciute G, Abdykanova A, Kume S et al (2018) The effect of geographical margins on cereal grain size variation: Case study for highlands of Kyrgyzstan. J Archaeol Sci: Rep 20:400-410

Narasimhan VM, Patterson N, Moorjani P et al (2019) The formation of human populations in South and Central Asia. Science 365(6457): eaat7487

Neef R, Cappers RTJ, Bekker RM, Boulos L (2012) Digital atlas of economic plants in archaeology. Groningen University Library, Eelde, Groningen, Barkhuis

Olivieri LM (2003) The survey of the Bir-kot hill. Archaeological map and photographic documentation. (IsIAO Memories and Reports, Series Minor 6). IsIAO, Rome

Olivieri LM (2011) The Last phases at Barikot: urban cults and preliminary chronology: data from the 2012 excavation campaign in Swat. J Inner Asian Art Archaeol 6:7-40

Olivieri LM (2012) The Last phases at Barikot: urban cults and sacred architecture. Data from the spring 2013 excavation campaign in Swat. J Inner Asian Art Archaeol 7:7-30

Olivieri LM (2017) Vajīrasthāna/Bazira and beyond: foundation and current status of the archaeological work in Swat. In: Ray HP (ed) Buddhism and Gandhara. An archaeology of museum collections. Routledge, London, pp 173-212

Olivieri LM (2021) Gandhara and North-Western India. In: GraecoBactrian T, Indo-Greek world (Routledge worlds series) (eds) Mairs R. Routledge, New York, pp 386-415

Olivieri LM, Iori E (2020) Beginnings and abandonment of and early historic town in the north-west of the subcontinent: Data from 2015 and 2016 excavation campaigns at Bir-kot-ghwandai, Swat (Pakistan). In: Religion, society, trade and kingship: art and archaeology in South Asia and along the Silk Road (5500 BCE5th century CE). (South Asian Art and Archaeology 2016, vol 1 (ed) Greaves LR, Greaves A. Dev Publishers \& Distribution, New Delhi, pp 79-103

Olivieri LM, Vidale M, Khan AN et al (2006) Archaeology and settlement history in a test area of the Swat valley: preliminary report on the AMSV project (1st Phase). East West 56:73-150

Olivieri LM, Marzaioli F, Passariello I et al (2019) A new revised chronology and cultural sequence of the Swat valley, Khyber Pakhtunkhwa (Pakistan) in the light of current excavations at Barikot (Bir-kot-ghwandai). Nuclear Instrum Methods Phys Res B 456:148-156

Pearsall DM (2000) Paleoethnobotany: a handbook of procedures. Academic Press, San Diego

Petrie CA, Bates J (2017) “Multi-cropping”, intercropping and adaptation to variable environments in Indus, South Asia. J World Prehist 30:81-130

Petrie CA, Thomas KD (2012) The topographic and environmental context of the earliest village sites in western South Asia. Antiquity 86 (334):1,055-1,067

Petrie CA, Bates J, Higham T, Singh RN (2016) Feeding ancient cities in South Asia: dating the adoption of rice, millet and tropical pulses in the Indus civilisation. Antiquity 90:1,489-1,504

Petrie CA, Singh RN, Bates J et al (2017) Adaptation to variable environments, resilience to climate change: investigating land, water and settlement in Indus, northwest India. Curr Anthropol 58:1-30

Pokharia AK (2007) Plant remains from Kanmer excavation 05-06. In: Osada T (ed) Linguistics, archaeology and the human past. Research Institute for Humanity and Nature, Indus Project, Kyoto, pp 30-31

Pokharia AK, Saraswat KS (1999) Plant economy during Kushana period (100-300 AD) at ancient Sanghol, Punjab. Pragdhara 9:75-121

Pokharia AK, Kharakwal JS, Srivastava A (2014) Archaeobotanical evidence of millets in the Indian subcontinent with some 
observations on their role in the Indus civilization. J Archaeol Sci 42:442-455

Pokharia AK, Mani BR, Spate M et al (2018) Early Neolithic agriculture (2700-2000 BC) and Kushan period developments (AD 100-300): macrobotanical evidence from Kanispur in Kashmir, India. Veget Hist Archaeobot 27:477-491

Pokharia AK, Sharma S, Tripathi D et al (2017) Neolithic- Early historic (2500-200 BC) plant use: The archaeobotany of Ganga Plain, India. Quat Int 443:223-237

Reddy SN (2003) Discerning palates of the past: an ethnoarchaeological study of crop cultivation and plant usage in India. (International Monographs in Prehistory, Ethnoarchaeological series 5) Berghahn Books, Oxford

Salunkhe A, Tamhankar S, Tetali S (2012) Molecular genetic diversity analysis in emmer wheat (Triticum dicoccon Schrank) from India. Genet Res Crop Evol 60:1-10

Saraswat KS (1980) The ancient remains of the crop plants at Atranjikhera (c. 2000-1500 BC). J Indian Bot Soc 59:306-319

Saraswat KS (1986) Ancient crop economy of Harappans from Rohira, Punjab (c. 2000-1700 BC). Palaeobotanist 35:32-38

Saraswat KS (1992) Archaeobotanical remains in ancient cultural and socioeconomical dynamics of the Indian subcontinent. Palaeobotanist 40:514-545

Saraswat KS (2004) Plant economy of early farming communities. In: Singh BP (ed) Early farming communities of the Kaimur. Publication Scheme, Jaipur, pp 416-535

Saraswat KS (2005) Agricultural background of the early farming communities in the Middle Ganga Plain. Pragdhara 15:145-177

Saraswat KS, Pokharia AK (2003) Palaeoethnobotanical investigations at early Harappan Kunal. Pragdhara 13:105-140

Sharif M, Thapar BK (1992) Food producing communities in Pakistan and northern India. History of civilizations of Central Asia 1:127-151

Sharma AK (2000) Early man in Jammu Kashmir and Ladakh. Agam Kala Prakashan, Delhi

Sharma AK (2013) Excavation at Gufkral (Jammu and Kashmir). BR Publishing House, New Delhi

Sherratt A (1983) The secondary exploitation of animals in the Old World. World Archaeol 15:90-104

Spate M, Zhang G, Yatoo M, Betts A (2017) New evidence for early 4th millennium вP agriculture in the Western Himalayas: Qasim Bagh, Kashmir. J Archaeol Sci: Rep 11:568-577

Spengler RN (2015) Agriculture in the Central Asian Bronze Age. J World Prehist 28:215-253

Spengler RN III (2019) Fruit from the sands: the Silk Road origins of the foods we eat. University of California Press, Berkeley

Spengler RN, Willcox G (2013) Archaeobotanical results from Sarazm, Tajikistan, an Early Bronze Age settlement on the edge: agriculture and exchange. Environ Archaeol 18:211-221

Spengler RN III, Frachetti MD, Fritz GJ (2013) Ecotopes and herd foraging practices in the steppe/mountain ecotone of Central Asia during the Bronze and Iron Ages. J Ethnobiol 33:125-147

Spengler RN, Frachetti MD, Doumani PN (2014) Late Bronze Age agriculture at Tasbas in the Dzhungar Mountains of eastern Kazakhstan. Quat Int 348:147-157

Spengler RN, Miller NF, Neef R et al (2017) Linking agriculture and exchange to social developments of the Central Asian Iron Age. J Anthropol Archaeol 48:295-308

Spengler RN, de Nigris I, Cerasetti B et al (2018) The breadth of dietary economy in Bronze Age Central Asia: Case study from Adji Kui 1 in the Murghab region of Turkmenistan. J Archaeol Sci: Rep 22:372-381

Srivastava C, Tewari DP (2011) Palaeoethnobotanical finds from ancient Naimisharanya, District Sitapur, UP during Kushana Period (AD 100-300). Man Environ 36:35-44

Stacul G (1976) Excavation at Loebanr III (Swāt, Pakistan). East West 26:13-30
Stacul G (1987) Prehistoric and protohistoric Swāt, Pakistan (c. 30001400 BC). IsMEO Reports and Memoirs, Rome

Stacul G (1993) Kalako-deray, Swāt: 1989-1991 excavation report. East West 43:69-94

Stevens CJ, Murphy C, Roberts R et al (2016) Between China and South Asia: A Middle Asian corridor of crop dispersal and agricultural innovation in the Bronze Age. Holocene 26:1,541-1,555

Taylor WTT, Shnaider S, Spengler R III et al (2019) Investigating ancient animal economies and exchange in Kyrgyzstan's Alay Valley. Antiquity 93(367):1-5

Tewari R, Srivastava RK, Saraswat KS et al (2008) Early farming at Lahuradewa Pragdhara 18:347-373

Thomas KD, Cartwright C (2010) The biological remains from Sheri Khan Tarakai. In: Tarakai SK, early village life in the borderlands of north-west Pakistan, Pakistan. (Bannu Archaeological Project Monographs, vol 1) (eds) Petrie CA, Khan F, Knox JR, Thomas KD. Oxbow, Oxford, pp 305-342

Turner NJ, Deur D, Mellott CR (2011) "Up on the mountain": ethnobotanical importance of montane sites In Pacific coastal North America. J Ethnobiol 31:4-43

Vidale M, Olivieri LM (2002) Painted rock shelters of the Swat valley: further discoveries and new hypotheses. East West 52:173-223

Vidale M, Micheli R, Olivieri L (2011) Iconography of protohistoric Swat and the agricultural intensification of Period IV (2nd Millennium BCE). J Asian Civilizations 34:97-126

Vidale M, Olivieri LM, Micheli R (eds) (2015) Excavations at the protohistoric graveyards of Gogdara and Udegram (ACT Field School Reports and Memoirs 3). Sang-e-Meel Publications, Lahore

Vishnu-Mittre, (1965) Floristic and ecological reconsiderations of the Pleistocene plant impressions from Kashmir. Palaeobotanist 13:308-327

Vishnu-Mittre (1972) The Neolithic plant economy of Chirand, Bihar. Palaeobotanist 21:18-22

Vishnu-Mittre (1984) Quaternary palaeobotany and palynology in the Himalaya: an overview. Palaeobotanist 32:158-187

Von Hinüber O (2020) The name of the city. In: Callieri P, Olivieri LM (eds) Ceramics from the excavations in the historic settlement at Bir-kot-ghwandai (Barikot) Swat, Pakistan (1984-1992). ACTField School Project Reports and Memoirs, Lahore, pp 53-55

Watson PJ (1976) In pursuit of prehistoric subsistence: a comparative account of some contemporary flotation techniques. Midcontinental J Archaeol 1:77-100

Watson AM (1983) Agricultural innovation in the early Islamic world: the diffusion of crops and farming techniques, 700-1100. Cambridge University Press, Cambridge

Weber SA (1991) Plants and Harappan subsistence: An example of stability and change from Rojdi. Routledge, London

Weber S (1999) Seeds of urbanism: palaeoethnobotany and the Indus Civilization. Antiquity 73:813-826

Weber SA (2003) Archaeobotany at Harappa: indications for change. In: Weber SA, Belcher WR (eds) Indus ethnobiology: new perspectives from the field. Lexington Books, Lanham, pp 175-198

Weber SA, Fuller DQ (2008) Millets and their role in early agriculture. Pragdhara 18:69-90

Zeb A, Khan SM, Ahmad H (2013) Wild plants of the Dughalgay valley, District Swat, Pakistan; traditional use and marketing. Emirates J Food Agric 25:1-10

Zhou X, Yu J, Spengler RN et al (2020) 5,200-year-old cereal grains from the eastern Altai Mountains redate the trans-Eurasian crop exchange. Nat Plants 6:78-87

Publisher's Note Springer Nature remains neutral with regard to jurisdictional claims in published maps and institutional affiliations. 